\title{
Meningkatkan Keterampilan Menulis Peserta Didik Melalui Whatsapp Diary Writing
}

\section{Zainab ${ }^{1 *}$, G. B. Java ${ }^{2}$, L. P. Artini ${ }^{3}$}

123 Jurusan Pendidikan Bahasa Inggris Universitas Pendidikan Ganesha

\section{ART I C L E I N F O}

Article history:

Revised February 03, 2021

Accepted April 08, 2021

Available online May 25, 2021

Kata Kunci:

Whatsapp Diary Writing

Keywords:

Whatsapp Diary Writing
Received January 21, 2021

\section{A B S T R A K}

Penelitian ini bertujuan untuk mengetahui penggunaan Whatsapp Diary Writing untuk meningkatkan kemampuan menulis peserta didik. Dalam hal ini, penulis melakukan Penelitian Tindkaan Kelas (PTK) yang terdiri dari tahap perencanaan, pelaksanaan, pengamatan dan rekfleksi. Sebelum memberikan perlakuan, peserta didik kebingungan dalam menulis dalam Bahasa Inggris dengan pemilihan kosa kata dan penggunaan struktur kalimat yang baik. Peserta didik memiliki kesadaran yang lemah terhadap tata cara penulisan yang baik dan benar. Peserta dtidak mempuyai waktu lebih untuk melakukan latihan menulis. Oleh karena itu, penulis memilih dalam Whatsapp Diary Writing untuk memberikan kesempatan lebih menulis kepada peserta didik. Dalam penelitian ini, penulis menggunakan dua jenis instrumen penilaian, yakni tes dan observasi untuk guru dan peserta didik. Setelah memberikan perlakuan, penulis menarik kesimpulan bahwa terjadi peningkatan keterampilan menulis peserta didik melalui Whatsapp Diary Writing.

\section{A B S T R A C T}

This study aims to find out the implementation of Whatsapp diary Writing to improve students writing skill. The researcher selected a Classroom Action Research (CAR) which consists of planning, acting, observing, and reflecting. Before doing the first cycle, the students were confused to write in a good order of word choice and grammar. The students also had lack of awareness to write something in the correct writing mechanic. The pupils did not have much time to practice their writing skill. So that, the researcher chose Whatsapp Dairy Writing to give lot of chance to practice outside of the class. The researcher used two kinds of research instruments namely the test and the observation sheets for teacher and students. After analyzing the data, the researcher finds that the students can improve their writing skill through Whatsapp Diary Writing.

\section{Pendahuluan}

Keberhasilan pendidikan dapat ditunjukkan dari kualitas pendidikan yang ada, dimana kualitas pendidikan itu meliputi kualitas proses maupun kualitas lulusan. Jadi pendidikan dikatakan berhasil apabila proses belajar- mengajarnya berjalan dengan baik serta menghasilkan output yang berkualitas. Di dalam peningkatan mutu pendidikan perlu efisiensi pendidikan, yang mempunyai arti bahwa proses pendidikan harus mencapai hasil yang maksimal dengan biaya yang wajar. Dalam pandangan yang lebih luas efisiensi pendidikan berkaitan dengan profesionalisme dan manajemen pendidikan yang di dalamnya mengandung disiplin, kesetiaan dan etos kerja. Hal ini kurang disadari oleh para penyelenggara pendidikan yang berada di daerah pada umumnya, yang pada gilirannya mengakibatkan munculnya permasalahan pada dunia pendidikan (Maesaroh, 1970).

Menulis menjadi kebutuhan penting bagi setiap orang yang terlibat dalam kegiatan sosial, ekonomi, pendidikan, teknologi dan lain-lain. Keterampilan menulis diperlukan pada semua lapangan pekerjaan dan bahkan dapat menentukan keberhasilan dalam suatu pekerjaan atau jabatan. Tulisan dapat membantu kita menjelaskan pikiran-pikiran kita. Tidak jarang kita menemukan apa yang sebenarnya kita pikirkan dan rasakan mengenai orang-orang, gagasan-gagasan, masalah-masalah dan kejadian-kejadian melalui proses menulis yang aktual.

Keterampilan menulis mempunyai peranan yang sangat penting dalam kehidupan sehari-hari. Keterampilan menulis merupakan syarat untuk berkecimpung dalam berbagai macam bidang atau kegiatan. Hal ini mengandung pengertian betapa pentingnya keterampilan dan kemampuan menulis dalam kehidupan sehari-hari. Menulis juga merupakan salah satu keterampilan berbahasa yang dipergunakan dalam komunikasi secara tidak langsung. Melalui kegiatan menulis, siswa diarahkan mampu berkomunikasi dengan menggunakan bahasa tulis. Dalam hal ini, diharapkan siswa mampu menuangkan gagasan atau idenya secara runtut dengan diksinya yang tepat, struktur yang benar sesuai dengan konteksnya.Dalam pembelajaran menulis, salah satu kompetensi dasar yang akan dikaji oleh peneliti adalah kegiatan menulis kembali dongeng pada aspek kesusastraan. Kompetensi dasar tersebut

Copyright (C) Universitas Pendidikan Ganesha. All rights reserved. 
yang harus ditempuh oleh siswa kelas VII semester I untuk mencapai salah satu tujuan pembelajaran. Melalui standar kompetensi tersebut siswa diharuskan untuk mampu mengubah dongeng yang pernah dibaca dengan cara menulisnya kembali sesuai dengan bahasanya sendiri.(Puspitasari and Rustono, 2014).

Menulis merupakan suatu keterampilan berbahasa yang dipergunakan untuk berkomunikasi secara tidak langsung, tidak secara tatap muka dengan orang lain Tarigan (1986:3). Menulis adalah membuat huruf (angka dan sebagainya) dengan pena

atau dapat juga diartikan melahirkan pikiran, perasaan, dengan tulisan (Depdiknas

2003:506). Dalam kegiatan menulis ini penulis haruslah terampil memanfaatkan grafologi, struktur bahasa dan kosa kata. Keterampilan menulis dapat dikuasai melalui latihan atau praktik yang banyak dan teratur. Artikel Ilmiah adalah sebuah karya tulis yang isinya mengungkapkan suatu pembahasan yang lengkap dan secara ilmiah ditulis oleh seorang penulis. Untuk memberitahukan sesuatu hal secara logis dan sistematis kepada para pembaca. Artikel ilmiah juga biasanya ditulis untuk mencari sebuah jawaban mengenai sesuatu hal yang diteliti dan untuk membuktikan kebenaran tentang sesuatu yang terdapat dalam objek tulisan tersebut. Biasanya tulisan ilmiah sering mengangkat tema seputar hal-hal yang baru (aktual) dan belum pernah ditulis oleh orang lain agar terlihat beda dan terkesan baik (Sismulyasih Sb, 2015).

Keterampilan menulis pada pembelajaran abad 21 menjadi salah satu aspek yang berpengaruh terhadap prestasi peserta didik. Melalui pengajran keterampilan menulis, peserta didik akan terlatih untuk neulis sebuah karangan berdasarkan kesesuaian isi dengan topic, kesistematisan isi, pilihan kata, keefektifan kalimat, penggunaan Ejaan Yang Disempurnakan (EYD) seperti penggunaan huruf capital dan tanda baca. Pada pembelajaran Bahasa Inggris, keterampilan menulis menjadi salah satu keterampilan yang harus dikuasai oleh peserta didik. (Raimes, 2014) menyatakan tiga alasan pentingnya menulis. Pertama, tulisan akan memperkuat bentuk gramatikal, ungkapan dan kosa kata yang disampaikan oleh guru di kelas. Kedua, untuk melatih peserta didik membiasakan diri berbahasa baik bagi dirinya sendiri maupun orang lain. Ketiga, melalui menulis peserta didik dilibatkan langsung dengan bahasa baik dengan siapapun.

Parera menyebutkan dalam Aljatila (2015) keterampilan menulis adalah keterampilan menggunakan ejaan, tanda baca, pembentukan kata, penggunaan kalimat, pemilihan kalimat, pemilihan kata, pengefektifan katam membahasakan pikiran dengan cermat, tepat, logis dan konsisten. Dengan kata lain, keterampilan menulis adalah keahlian dalam menuangkan ide atau gagasan dengan pemilihan dan penggunaan kata maupun kalimat dengan baik agar dapat diterima dan dipahami dengan mudah oleh pembaca. Berbeda dengan keterampilan berbiara yang bisa diajarkan dan diterapkan kapan pun selama proses pembelajaran, pengajaran keterampilan menulis memerlukan waktu khusus yang tidak sebentar. Jika keterampilan berbicara bisa terjadi saat diskusi, presentasi atau tanya jawab, keterampilan menulis hanya bisa terjadi pada aktifitas-aktifitas yang memang dikhususkan untuk menulis.

Oleh sebab itu, keterbatasan waktu untuk melatih peserta didik menulis Bahasa Inggris menjadi alasan utama yang menyebabkan peserta didik memiliki kemampuan rendah dalam menulis. Selain itu, rendahnya tingkat penguasaan Bahasa Inggris menjadi pemicu lainnya yang menyebabkan peserta didik belum menguasai keterampilan menulis. Tidak sedikitnya spek yang harus diperhatikan peserta didik untu menulis Bahasa Inggris membuat peserta didik tidak bisa bebas mengekspresikan ide kedalam sebuah tulisan. Dari hal yang paling mendasar seperti penggunaan EYD, pemilihan kosa kata, penggunaan struktur kata sampai kalimat-kalimat efektif atau istilah-istilah tertentu dalam Bahasa Inggris menjadi penyebab lain rendahnya keterampilan menulis peserta didik. Peserta didik menjadi kurang percaya diri dantakur membuat kesalahan dengan banyaknya aspek-aspek yang harus menjadi fokus dalam menulis.

Adapun tulisan yang baik menurut (Permanasari, 2017) adalah tulisan yang memiliki alur, isi, dan kebahasaan yang baik. Dari segi alur, tulisan yang baik mempunyai alur berpikir yang urut dan berkesinambungan. Dari segi isi, tulisan yang baik memuat informasi yang akurat dan kebenarannya dapat dipertanggungjawabkan secara ilmiah. Dari kebahasaan, karangan yang baik menggunakan ejaan yang benar, diksi yang variatif, kalimat yang efektif dan paragraf yang padu.

Diperlukan latihan independen yang terkontrol untuk melatih keterampilan menulis peserta didik. Latihan tersebut bisa dilakuakn tanpa mengganggu proses pembelajaran di kelas berupa penugasan yang dilakukan pada hari dan jam tertentu. Selain itu, memberikan kebebasan kepada peserta didik untuk menentukan topic yang ingin dituangkan dalam tulisan membuat peserta didik mampu mengembangkan ide cerita dengan kreatif dan bervariasi. Menulis buku harian atau diary writing adalah salah satu teknik yang akan melatih peserta didik untuk menulis, khususnya dalam Bahasa Inggris. Selain tidak mengganggu kegiatan belajar mengajar di kelas, peserta didik diberi kebebasan dalam mengembangkan cerita sesuai dengan apa yang diinginkan. Menurut (Klimova, 2015) diary writing adalah sebuah proses menulis yang mengijinkan peserta didik untuk menuliskan apapun seperti ide, gagasan, perasaan dan 
pengalaman sesuai dengan keinginan peserta didik. Dengan membuat catatan yang berisikan hal-hal yang sesuai dengan apa yang peserta didik mau secara terus menerus, peserta didik akan lebih cermat dengan penggunaan tata bahasa, kosa kata, maupun teknik penulisan.

(Nurhadi, 2007) menyatakan bahwa buku harian adalah catatan tentang apa yang kita kerjakan hari ini dan masa lampau, juga merupakan sumber informasi penting tentang peristiwa apa, kapan, siapa, bagaimana, mengapa, ddan dimana yang berhubungan dengan diri kita, untuk mengungkapkan segala sesuatu yang tidak mungkin diungkapkan kepada orang lain. Dengan menulis pada buku harian, seseorang bisa menuliskan kejadian-kejadian yang bersifat pribadi sekalipun. Buku harian yang biasanya berisi tentang kejadian-kejadian yang bersifat pribadi biasanya dijadikan konsumsi penulis saja. Namun, ada buku harian yang diperuntukkan untuk konsumsi publik. Biasanya buku harian tersebut berisi tentang suatu karya umum yang bisa dibaca oleh semua orang yang bisa bertujuan untuk menginspirasi banyak orang. Jennifer (Moon, 2010) menyatakan bahwa buku harian ditulis dalam kurun waktu tertentu yang bisa dilakukan dalam proses pembelajaran, lingkungan kerja atau proyek penelitian. Buku harian bisa berasal dari berbagai topic dan digunakan untuk berbagai tujuan.

Namun demikian, tidak semua orang mau dan senang menulis pada buku harian, pada usia beranjak dewasa misalnya. Hal tersebut terjadi karena ketidak tahuan seseorang dengan apa yang akan dituliskan, kapan harus menulis serta untuk apa menulis. Tidak hanya itu, keengganan seseorang untuk menulis karena ada rasa takut mengungkapkan kejadian atu peristiwa yang telah dialami dalam bentuk tulisan dan khawatir jiku tulisan tersebut dibaca oleh orang lain. Selain itu, keengganan anak-anak jaman sekarang dalam menulis bukuharian adalah karena adanya anggapan jika menulis buku harian adalah hanya untuk anak kecil dan terkesan kuno. Padahal, menulis buku harian sangat dianjurkan untukmembantu seseorang melepas tekanan dan masalah yang dialaminya.

Di Jepang, teknik menulis buku harian menjadi salah satu teknik pembelajaran yang dikenal dengan istilah Enikki. Menurut Mitsubishi Asian Children's Enniki Festa, Ennika adalah sebuah ilustrasi buku harian yang menggambarkan tentang kejadian dan ide-ide dalam keseharian dalam bentuk gambar yang ditambahkan dengan sebuah tulisan pendek. Dalam sebuah Enikki, penulis tidak hanya menggambar dan menulis tentang apa yang dilihat, dengar, lakukan atau pikirkan. Penulis juga mendeskripsikan tentang perasaan dan budaya. Dengan kata lain, Enikki adalah sebuah potret keseharian yang diungkapkan melalui gambar dan kalimat singkat. Buku harian sangat bersifat bebas mulai dari penulisin ide, isi, tata bahasa, format maupun tujuan dan bebas ditulis oleh siapapun. Buku harian memiliki tujuan dan manfaat bagi penulisnya terkhusus untuk berlatih mengungkapkan segala gagasan terpendamnya kedalam sebuah tulisan yang diharapkan dapat mengurangi tekanan dan stress yang dirasakan penulis.

Pada era digital ini, ada banyak media yang bisa digunakan untuk menulis buku harian baik secara konvensional maupun modern. Media jejaring sosial menjadi salah satu media yang paling banyak diminati pada saat ini untuk menuliskan ide, gagasan atau sekedar mencurahkan isi hati. Nasrullah (2005) mengatakan bahwa jejaring sosial memungkinkan penggunanya untuk berinteraksi satu sama lain, mulai dari pengiriman pesan teks, foto, video baik secara pribadi maupun publik. Salah satu media sosial tersebut adalah Whatsapp. Whatsapp adalah satu aplikasi media sosial yang coock untuk semua umur yang menawarkan fitur-fitur yang dapat dengan mudah diakses mulai dari anak-anak sampai orang tua.

Whatsapp dapat digunakan sebagai media pembelajaran sehingga proses pembelajaran dapat dilakukan di luar kelas baik melalui diskusi dalam Whatsapp Group maupun personal chat.

Aplikasi yang bermula sebagai alternative untuk mengirim pesan singkat (SMS) sekarang didukung dengan pengiriman dan penerimaan berbagai jenis media, mualai dari teks, foto, vide, dokumen, lokasi maupun rekaman suara. Pesan atau panggilan yang dikirim atau dilakukan diamankan dengan system end-to-end ecription dimana tidak ada pihak ketiga yang bisa membaca atau mendengar aktifitas penggunanya sekalipun oleh pihak Whatsapp. Sosial media ii memberikan kesempatan keapda penggunanya untuk berkomunikasi dimanapun tanpa hambatan.Fitur pengiriman teks yang sederhana dan aman memungkinkan para penggunanya untuk berkirim pesan dengan bebas hanya dengan menggunakan koneksi data yang kecil. Selain itu, aplikasi ini juga menawarkan fitur Group Chat yang memberikan ksempatan kepada penggunanya untuk tetap berkomunikasi dalam kelompok baik dengan kerabat maupun rekan kerja. Dalam Group Chat juga dilengkapi dengan fitur untuk berbagi pesan, foto, video dengan 256 orang dalam sekali waktu. Pengguna Whatsapp juga bisa memberi nama group atau mematikan atau mengatur pemberitahuan yang muncul dan masih banyak lainnya.

Tidak hanya itu, selain bisa dioperasikan melalui smartphone, Whatsapp juga meemungkinkan para penggunanya untuk mengakses melalui laptop dengan fitur Whatsapp Web. Dengan fitur tersebut, semua data di dalam Whatsapp akan secara otomatis tersinkron dengan laptop atau PC setelah pengguna menscan barcode yang telah disediakan. Para pengguna bisa mengunduh untuk Whatsaap untuk laptop atau PC atau langsung mengunjungin websites resminya. 
Para pengguna Whatsapp juga dengan mudah melakukan panggilan telepon suara maupun video. Dengan melakuakn panggilan tersebut, membuat pengguna Whatsapp bisa berkomunikasi dengan teman maupun kerabat sekalipun berada di Negara yang berbeda. Pengguna bisa melakukan percakapan face-toface secara langsung dengan penggunaan data internet yang tidak terlalu mahal. System end-to-end encryption pada Whatsapp membuat momen yang bersifat personal dapat dibagikan melalui Whatsapp. System tersebut memungkinkan hanya pengirim dan penerima pesan yang dapat membaca dan mendengarnya. Sehingga pengguna tidak perlu khawatir akan ada pihak ketiga diantara percakapan yang dilakukan.

Dengan menggunakan Whatsapp, pengguna bisa mengirim foto atau video secara langsung. Para pengguna bahkan bisa mengirim foto atau video dengan cepat sekalipun koneksi internet sedang berjalan lambat. Fitur lain yang ditawarkan sosial media ini adalah Voice Messages. Fitur tersebut mendukung para pengguna yang ingin mengucapkan sesuatu daripadda sekedar mengirimnya melalui pesan teks. Dengan hanya satu kali ketukan, pengguna bisa merekam Voice Message untuk sekedar menyapa atau bercerita yang lebih panjang. Sementara itu, Whatsapp Diary Writing (WDW) merupakan kombinasi yang memadukan penggunaan media sosial Whatsapp dengan teknik pembelajaran Diary Writing. Dalam hal ini, peserta didik diminta untuk membuat buku harian elektronik. Peserta didik diminta untuk mengirimkan sebuah karangan bebas sesuai dengan apa yang ingin dituliskan melalui Whatsapp secara personal kepada guru. Alasan penulis memilih mengkombinasikan media dan teknik pembelajaran tersebut adalah salah satunya untuk menghindari kejenuhan peserta didik dalam mengerjakan tugas yang berbasis paper based. Dengan menggunakan media yang dekat dengan kehidupan peserta didik diharapkan dapat memotivasi peserta didik untuk belajar, dalam hal ini untuk meningkatkan keterampilan menulis berbahasa Inggris khususnya. Sehingga teknik pembelajaran terbaru ini bisa tergolong ramah lingkungan, karena penulis mengurangi penggunaan kertas secara berlebihan. Selain itu, Whatsapp menjadi salah satu media sosial yang bisa dioperasikan baik oleh peserta didik, terlebih untuk guru dengan mudah. Guru yang tidak tergolong muda pun bisa mengoperasikannya dengan baik. Guru pun juga menggunakan Whatsapp Web melalui laptop atau PC sehingga guru bisa lebih leluasa mengoreksi dan memberikan komentar terhadap hasil kerja peserta didik.

Oleh karena itu, penulis memilih Whatsapp Diary Writing untuk melatih peserta didik menulis Bahasa inggris denga topic yang sesuai dengan keinginan serta membiasakan peserta didik menulis dengan menggunakan struktur kalimat dan teknik penulisan yang benar dan tepat melalui penugasan mandiri secara terkontrol. Hal tersebut menjadi tujuan dari penelitian ini yakni fokus intensif untuk melatih kemampuan menulis peserta didik tanpa mengganggu alokasi waktu pembelajaran di dalam kelas.

\section{Metode}

Karena peneltian ini bertujuan untuk meningkatkan keterampilan menulis peserta didik melalui Whatsapp Diary Writing dalam pembelajaran Bahasa Inggris, maka penulis menggolongkan penelitian ini sebagai Penelitian Tindakan Kelas (PTK) dengan tujuan untuk memecahkan masalah nyata yang terjadi di dalam kelas dan untuk meningkatkan kualitas praktik pembelajaran serta mutu hasil pendidikan melalui perbaikan praktik pembelajaran di kelas. Menurut Kemmis dan MC Taggart dalam Kunandar (2013) ada empat aspek pokok dalam PTK yakni: (1) Perencanaan, (Pelaksanaan), (3) Observasi, (4) Refleksi.

Pada tahap perencanaan, penulis mempersiapkan hal-hal yang diperlukan dalam pengajaran keterampilan menulis di dalam kelas berdasarkan materi yang akan diajarkan, termasuk bentuk penugasan yang akan diberikan kepada peserta didik di dalam kelas yang berhubungan dengan penugasan mandiri yang dilakukan di luar kelas. Penulis juga mempersiapkan lembar observasi yang bertujuan untuk mengamati proses pembelajaran di dalam kelas baik dari aktifitas yang dilakukan guru maupun peserta didik. Pada tahap pelaksanaan, penulis mengimplementasikan apa yang telah dirancang sesuai dengan Rencana Pelaksanan Pembelajaran (RPP). Pada tahap observasi, penulis beserta rekan pendidik lainnnya melakukan pengamatan proses pembelajaran di dalam kelas. Tahap refleksi menjadi tahap dimana penulis akan merefleksi apa yang telah dilakukan selama proses pengumpulan data di dalam kelas.

Data yang digunakan dalam penelitian ini terbagi dalam dua kategori, yakni data kuantitatif dan data kualitatif. Data kuantitatif diperoleh dari hasil tes tulis (post-test) diakhir siklus. Sedangkan data kualitatif didapatkan berdasarkan lembar observasi yang memuat informasi-informasi terkait hasil kerja peserta didik selama proses penerapan Whatsapp Diary Writing dalam upaya meningkatkan keterampilan menulis Bahasa Inggris.

Tes yang digunakan dalam penelitian ini adalah post-test yang diberikan diakhir siklus untuk mengukur peningkatan keterampilan menulis menggunakan Whatsapp Diary Writing dalam upaya meningkatkan keterampilan menulis Bahasa Inggris dalam kegiatan belajar-mengajar Bahasa Inggris. Data observasi diperoleh dari hasil pengamatan selama penugasan menulis di dalam maupun di luar kelas. 
Selain itu, data observasi juga diperoleh dari hasil wawancara tidak resmi dengan peserta didik baik ketika awal sebelum perlakuan dimulai sampai ppada akhir penerapan Whatsapp Diary Writing. Pada penelitian ini, penulis menggunakan dua teknik pengumpulan dat yakni tes berupa tes tulis dan lembar observasi. Tes tulis dilakukan satu kali diakhir siklus setelah penerapan Whatsapp Diary Writing untuk meningkatkan keterampilan menulis peserta didik. Sementara itu, lembar observasi diberikan ketika proses pengamatan penugasan di dalam kelas maupun di luar kelas berdasarkan hasil kerja peserta didik yang dilakukan di dalam maupun di luar kelas melalui pengiriman Whatsapp Diary Writing.

Setelah mengumpulkan data, penulis membuat evaluasi dan kesimpulan dari proses pengajaran keterampulan menulis menggunakan Whatsapp Diary Writing, penerapan teknik tersebut dan hasil posttest peserta didik setelah pengimple,entasian Whatsapp Diary Writing guna meningkatkan keterampilan menulis peserta didik.

Setelah mengumpulkan data, penulis menganalisis data tersebut berfokus pada aspek isi (ide atau gagasan), struktur kalimat, ketepatan pemilihan kosa kata dan mekanik penulisan ketika mengekspresikan sesuatu kedalam bentuk tulisan. Kemudian penulis menentukan rata-rata dan prosentase dari hasil tes tulis tersebut dengan rumus yang diambil dari Anthony (2016).

Rumusnya adalah sebagai berikut.

\begin{tabular}{ll}
\multicolumn{2}{l}{$\frac{\sum X}{N}$} \\
MX $=$ \\
Catatan: \\
MX $\quad$ : Rata-rata \\
$\sum X \quad$ : Total perolehan peserta didik
\end{tabular}

$\mathrm{N}$ : Banyaknya peserta didik

Sementara untuk menghitung prosentase keberhasilan dari hasil tes tulis menggunakan rumus sebagai berikut:

$$
\frac{F}{\boldsymbol{n}_{\mathrm{X} 100 \%}}
$$

Catatan:

P: Hasil Prosentase (\%)

$F_{\text {:Banyaknya peserta didik yang mendapat nilai diatas KKM }}$

$n$ : Banyaknya peserta didik

Sedangkan untuk menganalisis data kualitatif, penulis mendeskripsikan hasil observasi berdasarkan lembar observasi yang telah diisi oleh penulis dan rekan pendidik lainnya.

\section{Hasil Dan Pembahasan}

Berdasarkan hasil wawancara informal, peserta didik menyebutkan beberapa alasan ketika penulis selaku guru Bahasa Inggris menanyakan tentang apa saja hambatan yang ditemui dalam menulis Bahasa Inggris. Banyak dari peserta didik yang merasa kesulitan dalam menentukan kosa kata yang sesuai dengan konteks ketika akan menulis, khususnya menulis dalam berbahasa Inggris. Sedikitnya perbendaharaan kosa kata yang peserta didik miliki membuat hasil tulisan tidak bervariasi dan monoton. Tidak sedikit dari peserta didik yang masih kebingungan dengan perubahan bentuk kata kerja seperti penambahan huruf -s atau -es, -d atau -ed. Dengan kata lain kemampuan peserta didik masih lemah dalam menyusun struktur kalimat yang sesuai dengan konteks dan aturan dalam Bahasa Inggris. Selain itu, peserta didik juga menyebutkan alasan lain mengapa keterampilan menulis peserta didik dikategorikan rendah. Alasan tersebut adalah karena terbatasnya waktu untuk berlatih menulis Bahasa Inggris.

Selain itu, dilihat dari data yang diperoleh menunjukkan bahwa hanya ada 11 dari jumlah total 32 peserta didik yang mendapat nilai sama dengan atau diatas 81 sebagai nilai terendah mata pelajaran Bahasa Inggris di sebuah sekolah di Singaraja.

Oleh karena itu, pengajaran di kelas tersebut memerlukan sebuah perlakuan atau treatment untuk meningkatkan keterampilan menulis Bahasa Inggris. Guru selaku penulis memilih Whatsapp Diary Writing sebagai treatment karena teknik tersebut dapat membantu peserta didik meningkatkan keterampilan menulis dengan membiasakan diri menulis sesuai keinginan mereka dengan teknik penulisan yang baik dan benar.

Setelah menemukan masalah dan solusi dari masalah tersebut, penulis menyiapkan materi, RPP, dan media untuk diaplikasikan selama proses penerapan perlakuan tersebut. Penulis juga akan 
menyiapkan lembar observasi yang akan digunakan selama penerapan Whatsapp Diary Writing dalam upaya meningkatkan keterampilan menulis peserta didik.

Penelitian ini dilakukan hanya dalam satu siklus. Hal tersebut disebabkan karena dalam satu siklus yang terdiri dari tiga kali sesi perlakuan dan satu kali pertemuan untuk post-test peserta didik sudah menunjukkan peningkatan yang ditunjukkan dari hasil post-test yang telah mencapai indikator pencapaian.

Selama perlakuan pertama, mulai dari pengiriman Whatsapp Diary Writing yang pertama kali diketahui bahwa hampir semua dari peserta didik belum terbiasa untuk menulis dengan menggunakan ejaan ang disempurnakan dengan baik dan benar. Berkut ini adalah salah satu contoh hasil kerja peserta didik.

Dear diary

i am very lazy to go to school this week because many assignments have to be collected this week and also many tests

Sorry miss, i'm late to send my diary because I was sick yesterday

Thank you

Selanjutnya, bukti tersebut diperkuat dengan hasil tugas peserta didik yang pada penugasan menulis di dalam kelas ketika diminta untuk membuat cerita pendek dan sederhana berdasarkan kalimat yang telah dibuat sebelumnya. Dibawah ini adalah salah satu hasil penugasan menulis di dalam kelas.

$i$ have one brother and one sister. my sister want to collect coin because of a donation. my brother sell his helmet because he want to helps his siter. He think he's the real man because he want to help many people. My brother likes photography so he takes a photo of a beautiful view. i love them so much.

Namun, setelah guru mengulas dan menekankan pentingnya memperhatikan penggunaan huruf capital dan tanda baca dalam menulis sebuah karangan, kemampuan menulis peserta mengalami peningkatan. Hal tersebut dapat dilihat dari hasil tulisan peserta pada pengiriman Whatsapp Diary Writing yang kedua dibawah ini dengan subjek penelitian yang sama.

Dear diary,

Today I am very lazy to do something because I feel unwell since 2 days ago. I am not feeling well because when I go to school I was raining. And later today I began to feel fever, when I was in school I felt sleepy.

Thank you,

Interesting Man :)

Penulis memutuskan untuk fokus pada satu hal yang ingin dikoreksi pada tiap perlakuan yang berlangsung. Hal tersebut bertujuan agar peserta didik lebih mudah untuk mempelajari dan fokus dan apa yang harus diperhatikan dalam menulis sebuah karangan khususnya berbahasa Inggris. Mengingat ada beberapa masalah yang harus dipecahkan untuk meningkatkan keterampilan menulis peserta didik dalam kelas tersebut. Sehingga dalam perlakuan pertama ini, penulis memutuskan untuk fokus pada teknik penulisan yang menjadi hal yang paling mendasar dalam membuat tulisan yang baik.

Dari semua tahapan yang berlangsung pada perlakuan kedua ini menunjukkan bahwa peserta didik mengalami peningkatan kemampuan memilih kosa kata dalam Bahasa Inggris yang sesuai dengan konteks mengalami peningkatan. Hal tersebut bisa dilihat dari hasil kerja peserta didik berikut ini mulai dari pengiriman diary yang pertama, penugasan menulis di dalam kelas sampai penugasan menulis di rumah yang kedua.

Penugasan menulis di luar kelas yang pertama:

Dear miss

One week ago, I and my friends had activity for relaxetion, we went to swiming pool in Bukti village its name air sanih pool. At there i and my friend relaxing our body, and swam, I can't swiming but i had solution to rental buoy. We spent my time in there

Dari hasil penugasan tersebut bisa disimpulkan bahwa peserta didik masih belum bisa menentukan pilihan kosa kata yang cocok sesuai dengan konteksnya. Namun usai memberikan ulasan baik secara personal maupun secara umum di dalam kelas, ada peningkatan yang terlihat dari hasil penugasan menulis peserta didik. Hal tersebut bisa dilihat dari hasil kerja peserta didik dari penugasan menulis di dalam kelas dan di luar kelas dibawah ini.

Penugasan menulis di dalam kelas seccara berkelompok:

One day Restu is walking around the jungle and he see Widi is cutting the tree.

Restu : Hey Widi. Why do you cut the tree?

Widi : That's my tree. So that's up to me.

landslide.

Restu : I remind you if you cut the tree there will be a big disasater happer such as flood or

Widi : I don't care about that. Go away. 
Restu : Okay, I go. I just remind you.

Two months later, the rainy season comes and the flood happens.

Penugasan menulis di luar kelas yang kedua:

Dear miss

2 days ago, my friends and I went to swiming pool again but in different location. Its name is Jembong Pool. The water of Jembong pool is from Jembong Water Fall in Ambengan Village. It's very cold there because its located in the hills. We swam very happy in swimming pool. But I was disappointed with myself because my immune was being drop. I had a flu so I couldn't swim for longer time. Until now I still have a flu.

Dari dua hasil penugasan tersebut terlihat jika peserta didik mengalami peningkatan terutama dalam pemilihan kosa kata yang digunakan. Selain itu , berdasarkan ulasan yang diberikan pada perlakuan kedua, terlihat jika peserta didik mulai terlatih untuk menggunakan huruf kapital dengan baik dan benar.

Semua tahapan yang berlangsung pada perlakuan ketiga ini dapat membantu untuk meningkatkan keterampilan menulis peserta didik menjadi lebih baik lagi terutama pada bagian menggunakan struktur kalimat yang sesuai dengan konteks dan aturan dalam Bahasa Inggris. Berikut ini adalah salah satu contoh penugasan menulis pertama yang dikirimkan melalui Whatsapp.

Dear diary,

Sorry miss, I am late. Because yesterday I dont have data celuler.

Now, I can save my money. This is my progress to save my money. Although just a little. But, this so helpul for me.

Thanks miss

Dari hasil tulisan tersebut dapat diketahui jika peserta didik masih belum bisa menggunakan struktur kalimat yang sesuai dengan konteks dalam Bahasa Inggris. Pada tulisan tersebut, peserta didik menggunakan kata don't untuk kejadian yang sudah terjadi dimasa lampau yesterday. Tidak hanya itu, peserta didik juga tidak menempatkan kata kerja is pada kalimat this so helpful for me.

Pada penugasan menulis di dalam kelas, peserta didik juga sudah mulai sadar dan segera memperbaiki kesalahan pada penggunaan struktur kalimat pada tugas mereka seperti yang bisa dilihat dibawah ini.

In our group opinion, this song is very easy listening. It has good melody and easy lyric to say. This song tells us about love. Love is not only about words but it needs proof. It needs the real action to show our feeling rather than just saying I love you to our love. Our love wants to see our effort to know the real love from us.

Sementara itu, setelah memberikan feedback pada pertemuan tanggal 28 Februari 2019 yang menekankan pada penggunaan struktur kalimat dalam Bahasa Inggris, kemampuan peserta didik dalam bagain itu mulai mengalami peningkatan. Hal tersebut bisa dilihat dari hasil kerja dibawah ini.

Dear diary,

During the holidays to celebrate Silent day or "Hari Raya Nyepi", I was happy because I could do it in my village and gathered with my big family.

Beside that, a day before "Hari Raya Nyepi", there was event parading ogoh-ogoh is often called "Pengerupukan". I enjoyed seeing many ogoh-ogoh while thinking that Balinese people have an artistic spirit. Then, I hope Balinese tradition could to be saved.

Thanks miss

Penulis memilih teknik Whatsapp Diary Writing untuk meningkatkan keterampilan menulis peserta didik kela XI MIPA 8 SMA Negeri 1 Singaraja. Whatsapp Diary Writing adalah salah satu teknik untuk membantu peserta didik meningkatkan keterampilan menulis melalui pembiasaan menuangkan ide, gagasan atau perasaan dalam bentuk tulisan yang dikirimkan melalui pesan teks pribadi melalui Whatsapp dalam kurun waktu tertentu secara berkelanjutan.

Dengan pembiasaan menulis atau latihan independen yang terkontrol dalam kurun waktu tertentu, peserta didik menjadi terbiasa menulis dengan menggunakan EYD yang baik dan benar. Tidak hanya itu, kemampuan peserta didik dalam menetukan kosa kata yang sesuai dengan konteks juga meningkat. Lebih kompleks lagi, dengan pembiasaan menulis tersebut, peserta didik secara tidak langsung belajar tentang penggunaan struktur kalimat yang sesuai dengan konteks cerita dalam Bahasa Inggris.

Dari hasil post-test yang telah dilakukan, dapat diketahui jika terjadi peningkatan terhadap kemampuan menulis peserta didik. Peserta didik mengalami peningkatan terhadap kemampuan menulis dengan memperhatikan EYD yang baik dan benar setelah mendapatkan tiga kali perlakuan pembiasaan menulis selama tiga minggu. Peningkatan juga terjadi terhadap aspek pemilihan kosa kata dan gramatikal yang digunakan peserta didik dalam menulis tugas ulasan lagu yang dilakukan di dalam kelas selama 30 menit. Berbeda dengan saat sebelum mendapatkan perlakuan, peserta didik tampak tidak percaya diri dalam menuangkan ide dalam bentuk tulisan dengan dalam waktu 30 menit. Pada penilaian post test 
tingkat kepercayaan diri peserta didik meningkat karena kemampuan penguasaan teknik peserta didik juga meningkat.

Dari hasil post-test tersebut dapat diketahui bahwa hanya ada 11 peserta didik yang belum mengalami peningkatan keterampilan menulis. Namun, 8 dari jumlah tersebut mendapat nilai diatas KKM. Satu peserta didik mengalami peningkatan namun hasil post test masih dibawah KKM. Sehingga ada empat peserta didik yang mendapat nilai dibawah KKM pada saat post test. Faktor yang menyebabkan peserta didik belum mengalami peningkatan keterampilan menulis adalah rendahnya motivasi peserta didik untuk menulis dan kurangnya minat peserta didik untuk mendapat hasil terbaik karena penugasan ini tidak termasuk dalam penilaian utama penugasan Bahasa Inggris.

Dengan kata lain, ada 87.5\% peserta didik sukses mendapat nilai diatas KKM setelah penerapan Whatsapp Diary Writing dilakukan dalam tiga perlakuan dalam satu siklus penelitian. Oleh karena itu, penulis memutuskan untuk mengakhiri siklus penelitian ini. Peningkatan keterampilan menulis peserta didik tersebut dapat dilihat dari grafik dibawah ini.

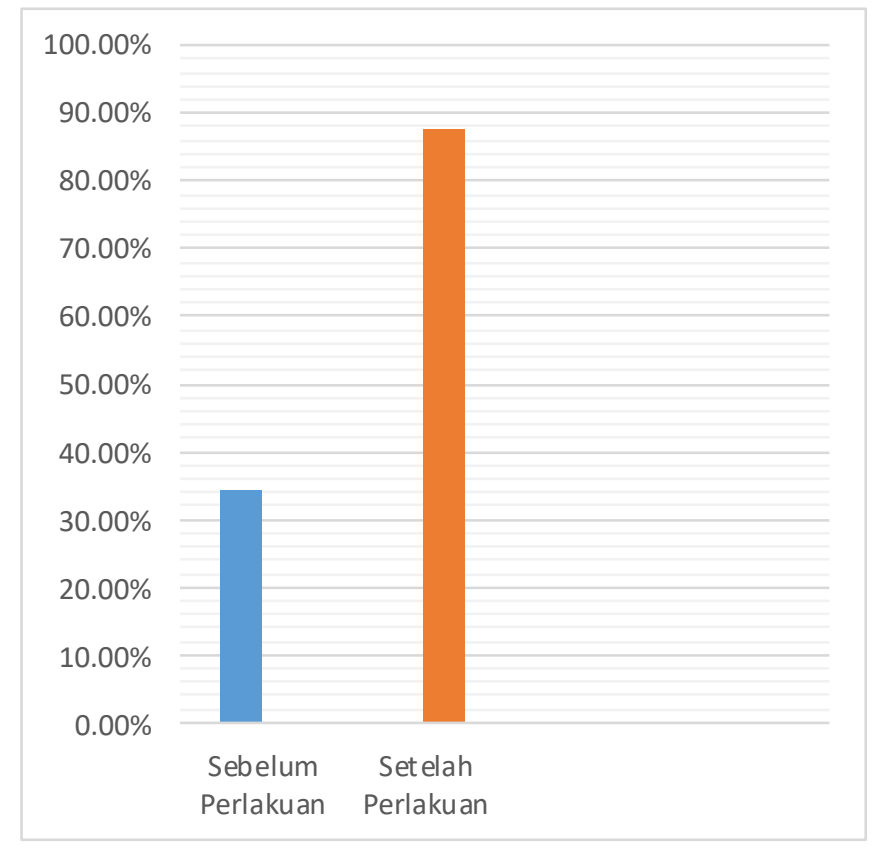

Gambar 1. Grafik Peningkatan Keterampilan Menulis Sebelum dan Sesudah Perlakuan

Dari grafik tersebut dapat diketahui bahwa ada peningkatan sebesar $53.2 \%$ pada keterampilan menulis peserta didik sebelum dan setelah penerapan Whatsapp Diary Writing dalam pembelajaran keterampilan menulis Bahasa Inggris. Jika sebelum perlakuan, hanya 11 peserta didik yang mendapat nilai diatas KKM, setelah perlakuan dilakuakan, ada 28 peserta didik yang mendapat nilai diatas KKM. Sebelum perlakuan ada 21 peserta didik yang mendapatkan nilai dibawah KKM. Jumlah tersebut menurun menjadi hanya 4 peserta didik yang mendapat nilai dibawahnilai minimal.

\section{Simpulan}

Penulis dapat menyimpulkan bahwa berdasarkan data post test yang telah dilakukan setelah penerapan Whatsapp Diary Writing, keterampilan menulis peserta didik meningkat. Sehingga dapat dikatakan bahwa penerapan Whatsapp Diary Writing dapat meningkatkan keterampilan menulis peserta didik. Penerapan Whatsapp Diary Writing dalam peningkatan keterampilan peserta didik di sebuah sekolah di Singaraja dilakukan sebagai penugasan menulis di luar kelas. Hal ini dilakukan agar tidak mengganggu jam pelajaran di dalam kelas mengingat penyelesaian masalah yang ditemukan di kelas tersebut meminta peserta didik melakukan penugasan menulis yang terkontrol dan dilakukan secara terus menerus. Dalam penerapannya, peserta didik diminta untuk mengirimkan diary writing pada waktu tertentu yakni pada hari Senin dan Kamis mulai pukul 19.00 - 22.00 WITA. Selanjutnya, penulis selaku guru Bahasa Inggris akan membalas pesan tersebut dan mengomentari hasil kerja peserta didik melalui Whatsapp. Tidak lupa, guru juga mendiskusikan hasil kerja peserta didik secara keseluruhan pada tiap pertemuannya. Guru menekankan hal-hal penting yang harus diperhatikan peserta didik dalam menulis karangan menggunakan Bahasa Inggris. 
Untuk meningkatkan keterampilan menulis, ada beberapa saran yang ditujukan untuk guru Bahasa Inggriis dan peneliti lainnya. Penulis berharap penelitian ini dapat membantu Guru Bahasa Inggris mengaplikasikan Whatsapp Diary Writing untuk meningkatkan keteramplan menulis peserta didik. Dengan menggunakan teknik ini, penulis berharap dapat membantu guru untuk memberikan penugasan menulis di luar kelas yang dilakukan secara terkontrol dan rutin dalam kurun waktu tertentu. Dengan menggunakan teknik ini, guru memberikan kebebasan kepada peserta didik untuk memilih topik yang ingin dituliskan. Guru hanya disarankan untuk memberikan tema secara luas. Sehingga, peserta didik memiliki kebebasan ruang dan waktu untuk berkespresi menuangkan ide dan gagasannya kedalam sebuah tulisan.

Setelah penerapan Whatsapp Diary Writing dalam proses pembelajaran menulis Bahasa Inggris, diharapkan peserta didik dapat meningkatkan keterampilan menulis melalui apa yang telah didapatkan baik dari feedback yang dilakukan guru secara personal melalui Whatsapp maupun ulasan guru secara umum di dalam kelas. Dengan penerapan teknik ini selama proses pembelajaran, peserta didik diharapkan menjadi terbiasa untuk menulis Bahasa Inggris dengan teknik maupun aturan penulisan Bahasa Inggris dengan baik dan benar sehingga dapat meningkatkan tingkat kepercayaan diri peserta didik untuk menuangkan ide atau gagasan ke dalam bentuk tulisan.

Penulis berharap jika hasil penelitian ini dapat digunakan untuk peneliti lainnya sebagai referensi untuk menyusun penelitian yang lebih baik kedepannya. Besar harapan penulis jika teknik ini dapat diaplikasikan untuk tingkat pendidikan lainnya. Namun demikian, pemilihan tema dan bentuk kegiatan berdasarkan tingkat kesulitannya perlu dipertimbangkan demi keberhasilan proses pembelajaran.

\section{Daftar Pustaka}

Klimova (2015) Diary Writing as A Tool dor Student' Self Reflection and Teacher's Feedback in the Course of Academic Writing. Procedia - Social and Behavioral Sciences.

Maesaroh, S. (1970) 'Peranan Metode Pembelajaran Terhadap Minat Dan Prestasi Belajar Pendidikan Agama Islam', Jurnal Kependidikan, 1(1), pp. 150-168. doi: 10.24090/jk.v1i1.536.

Moon, J. (2010) Assessment: Learning Journals and Logs. United Kingdom. UCD Teaching and Learning.

Nurhadi (2007) Bahasa Indonesia untuk SMP Kelas VII. Malang: Erlangga.

Permanasari (2017) 'Kemampuan Menulis Teks Deskripsi Siswa Kelas VII SMP Negeri 1 Sumber Jaya Lampung Barat', Jurnal Pesona.

Puspitasari, E. H. and Rustono, H. B. (2014) 'Peningkatan Keterampilan Menulis Kembali Dengan Bahasa Sendiri Melalui Media Film Dongeng', Jurnal Pendidikan Bahasa dan Sastra Indonesia, 3(1), pp. 1-8.

Raimes (2014) Technique in Teaching Writing. New York: Oxford University Press.

Sismulyasih Sb, N. S. S. (2015) 'Peningkatan Keterampilan Menulis Manuskrip Jurnal Ilmiah Menggunakan Strategi Synergetic Teaching Pada Mahasiswa Pgsd Unnes', Primary: Jurnal Pendidikan Guru Sekolah Dasar, 4(1), p. 64. doi: 10.33578/jpfkip.v4i1.2724. 